\title{
Arthrobacter defluvii sp. nov., 4-chlorophenol- degrading bacteria isolated from sewage
}

\author{
Correspondence \\ Jung-Sook Lee \\ jslee@kribb.re.kr
}

\author{
Kwang Kyu Kim, Keun Chul Lee, Hee-Mock Oh, Mi Jeong Kim, \\ Mi Kyung Eom and Jung-Sook Lee
}

\begin{abstract}
Korean Collection for Type Cultures, Biological Resource Center, Korea Research Institute of Bioscience and Biotechnology, 52 Eoeun-dong, Yuseong-gu, Daejeon 305-806, Republic of Korea
\end{abstract}

The genus Arthrobacter within the family Micrococcaceae was first established by Conn \& Dimmick (1947) and the description was emended by Koch et al. (1995) with the reclassification of Micrococcus agilis to this genus as Arthrobacter agilis. Members of the genus Arthrobacter comprise Gram-positive, catalase-positive, actinomycetecoryneform bacteria having a high DNA G +C content (Keddie et al., 1986; Jones \& Keddie, 1992). They have been divided into two groups on the basis of their peptidoglycan, which contains lysine as the diamino acid. Members of group I (including the type species, Arthrobacter globiformis) contain a peptidoglycan of $\mathrm{A} 3 \alpha$ type in which cross-linkage is made by interpeptide bridges consisting of monocarboxylic L-amino acids or glycine, or both, whereas members of group II contain a peptidoglycan of A4 $\alpha$ type in which cross-linkage is made by interpeptide bridges involving a dicarboxylic acid

Abbreviation: 4-CP, 4-chlorophenol.

The GenBank/EMBL/DDBJ accession numbers for the $16 \mathrm{~S}$ rRNA gene sequences of strains $4 \mathrm{C} 1-\mathrm{a}^{\top}$ and 4C1-b are $\mathrm{AM} 409361$ and AM409362, respectively.

A neighbour-joining phylogenetic tree based on 16S rRNA gene sequences showing the positions of strains $4 \mathrm{C} 1-\mathrm{a}^{\top}$ and $4 \mathrm{C} 1-\mathrm{b}$ among all described Arthrobacter species (with the exclusion of Arthrobacter viscosus) is available as supplementary material with the online version of this paper.
(Schleifer \& Kandler, 1972; Stackebrandt et al., 1983). Two exceptions to this are Arthrobacter duodecadis and Arthrobacter viscosus, which have a peptidoglycan of A4 $\gamma$ or Al $\gamma$ type, respectively. Consequently, A. duodecadis has been reclassified as Tetrasphaera duodecadis (Ishikawa \& Yokota, 2006), but the position of A. viscosus remains uncertain. At the time of writing, the genus Arthrobacter contains 53 recognized species, representative strains of which have been isolated from a variety of environmental sources including soil, air, water, oil brine, plants, biofilms, cyanobacterial mats, sediment, poultry litter, cheese, human clinical specimens and animal specimens (e.g. cows' milk, fish, flies and seals). Arthrobacter oryzae and Arthrobacter humicola have been described recently (Kageyama et al., 2008).

During the screening of 4-chlorophenol (4-CP)-degrading bacteria from sewage flowing into Geumho River near the Daegu industrial complex in Korea, strains $4 \mathrm{C} 1-\mathrm{a}^{\mathrm{T}}$ and 4C1-b were recovered, showing creamy white colonies when grown on R2A agar (Difco) at $25{ }^{\circ} \mathrm{C}$. On the basis of $16 \mathrm{~S}$ rRNA gene sequence comparisons, the two strains were found to belong to the genus Arthrobacter. For further classification, they were subjected to a polyphasic investigation.

A sewage sample was initially stimulated with 50 p.p.m. $(0.39 \mathrm{mM})$ 4-CP and the stimulated culture was then 
diluted serially in $0.85 \%$ saline solution. Aliquots of each serial dilution were spread on R2A agar and incubated at $25{ }^{\circ} \mathrm{C}$ for 14 days. Two creamy white colonies, designated strains $4 \mathrm{C} 1-\mathrm{a}^{\mathrm{T}}$ and $4 \mathrm{C} 1-\mathrm{b}$, respectively, were isolated and subcultivated onto R2A agar at $25{ }^{\circ} \mathrm{C}$ for $48 \mathrm{~h}$. For most experiments, the strains were cultivated on R2A agar or broth at $30{ }^{\circ} \mathrm{C}$ for $48 \mathrm{~h}$. For analysis of fatty acids, the strains were cultivated on trypticase soy agar (Difco) at $30{ }^{\circ} \mathrm{C}$ for 48 h. Arthrobacter chlorophenolicus DSM $12829^{\mathrm{T}}$, Arthrobacter oxydans DSM 20119 ${ }^{\mathrm{T}}$, Arthrobacter polychromogenes DSM 20136 ${ }^{\mathrm{T}}$, Arthrobacter scleromae JCM $12642^{\mathrm{T}}$ and Arthrobacter sulfonivorans DSM $14002^{\mathrm{T}}$ were used as reference strains under the same conditions.

The Gram reaction was performed as described by Gerhardt et al. (1994). Cell morphology and motility were observed under a phase-contrast microscope (Optiphot; Nikon), at $\times 1000$ magnification, with cells grown for 17 days. Motility was tested by the hanging-drop technique (Skerman, 1967). Oxidase activity was tested by using $1 \%$ tetramethyl- $p$-phenylenediamine (Tarrand \& Groschel, 1982 ) and catalase activity was tested by using $3 \% \mathrm{H}_{2} \mathrm{O}_{2}$. Growth was investigated at different temperatures $(5,10$, $15,20,25,30,37$ and $42{ }^{\circ} \mathrm{C}$ ), at different $\mathrm{NaCl}$ concentrations $(1,2,3,5$ and $10 \%)$ and at $\mathrm{pH} 5-11$ (increments of $1 \mathrm{pH}$ unit). For the $\mathrm{pH}$ experiments, appropriate biological buffers were used, as follows: $\mathrm{Na}_{2} \mathrm{HPO}_{4} / \mathrm{NaH}_{2} \mathrm{PO}_{4}$ buffer was used for $\mathrm{pH} 5-7$, and $\mathrm{Na}_{2} \mathrm{CO}_{3} / \mathrm{NaHCO}_{3}$ buffer was used for $\mathrm{pH}$ 8-11 (Bates \& Bower, 1956; Gomori, 1955). Hydrolysis of casein and starch was tested on casein agar and starch agar (Difco). The $\mathrm{H}_{2} \mathrm{~S}$ production test was performed on triple-sugariron agar (BBL). Carbon source utilization tests, acid production tests and additional physiological tests were performed by using API 20NE, API 20E, API 32GN, API 50 $\mathrm{CH}$ and API ZYM galleries according to the manufacturer's instructions (bioMérieux).

For determining vitamin requirements, strains were grown in M9 medium (Miller, 1972) containing $0.2 \%(\mathrm{w} / \mathrm{v})$ glucose and $/$ or $0.5 \% \quad(\mathrm{v} / \mathrm{v})$ vitamin solution (DSM catalogue no. 461). To check for utilization of nicotine and production of pigment, strains were cultivated on nicotine agar containing $4 \%$ nicotine (N2067; Sigma), $0.2 \% \mathrm{KH}_{2} \mathrm{HPO}_{4}, 0.5 \% \mathrm{KCl}, 0.01 \%$ yeast extract, $0.0025 \%$ $\mathrm{MgSO}_{4}, 0.0025 \% \mathrm{FeSO}_{4}$ and $1.5 \%$ Bacto agar (Difco). Strains were grown on peptone-carbohydrate agar, containing $1 \%$ peptone, $1 \%$ glucose, $0.5 \% \mathrm{NaCl}$ and $2 \%$ Noble agar (Difco), to determine production of blue pigments characteristic of A. polychromogenes.

The ability of strains $4 \mathrm{C} 1-\mathrm{a}^{\mathrm{T}}$ and $4 \mathrm{C} 1-\mathrm{b}$ to degrade different concentrations of 4-CP was determined in broth cultures. Cells were pregrown in M9 medium, containing 50 p.p.m. 4-CP as a sole carbon source, to stationary phase. Pregrown cells were then inoculated into M9 medium containing 4-CP concentrations of 100-300 p.p.m. (at increments of 50 p.p.m.). Growth was measured by determining $\mathrm{OD}_{600}$ with a Beckman DU 640 spectropho- tometer. The 4-CP concentration in broth cultures was determined by measuring the absorbance of the supernatant at $280 \mathrm{~nm}$ with a Beckman DU 640 spectrophotometer and relating the value to a standard curve prepared from analysis of sterile M9 medium (Westerberg et al., 2000).

Fatty acid methyl esters were prepared and analysed as described by Klatte et al. (1994) by using the standard Microbial Identification System (MIDI Inc.) for automated gas chromatographic analysis (Sasser, 1990; Kämpfer \& Kroppenstedt, 1996). Isoprenoid quinones were extracted with chloroform/methanol $(2: 1, \mathrm{v} / \mathrm{v})$ and were purified by using TLC on Kieselgel $60 \mathrm{~F}_{254}$ plates (Merck; $20 \times 20 \mathrm{~cm}$, $0.5 \mathrm{~mm}$ thickness) with petroleum ether/diethyl ether $(9: 1, \mathrm{v} / \mathrm{v})$ as the solvent. The identities of the quinones were determined by using reversed-phase HPLC analysis, as described by Shin et al. (1996). Purified cell-wall preparations were obtained as described by Schleifer \& Kandler (1972). Amino acids and peptides in cell-wall hydrolysates were analysed by two-dimensional TLC on cellulose plates by using the solvent systems described by Schleifer \& Kandler (1972). Cell-wall sugars were analysed according to the procedures of Staneck \& Roberts (1974).

Extraction of genomic DNA, PCR-mediated amplification of the 16S rRNA genes and sequencing of purified PCR products were carried out according to Rainey et al. (1996). The 16S rRNA gene sequences were aligned with published sequences retrieved from EMBL by using CLUSTAL_X (Thompson et al., 1997) and were edited by using BioEdit (Hall, 1999). Phylogenetic trees were constructed on the basis of the neighbour-joining (Saitou \& Nei, 1987) and maximum-parsimony (Fitch, 1971) methods; distances were estimated according to the method of Jukes \& Cantor (1969) by using MEGA version 2.1 (Kumar et al., 2001). The resultant tree topologies were evaluated by bootstrap analysis (Felsenstein, 1985) based on 1000 resampled datasets. The DNA $\mathrm{G}+\mathrm{C}$ content was determined by HPLC after hydrolysis, as described by Tamaoka \& Komagata (1984), and non-methylated $\lambda$ DNA (Sigma) was used as a standard. DNA-DNA hybridization to determine genomic relatedness was performed fluorometrically according to the method of Ezaki et al. (1989) by using DNA probes labelled with photobiotin (A1935; Sigma) and 96-well microdilution plates (Greiner BioOne) at $50{ }^{\circ} \mathrm{C}$.

Strains $4 \mathrm{C} 1-\mathrm{a}^{\mathrm{T}}$ and $4 \mathrm{C} 1-\mathrm{b}$ formed visible colonies (about $1 \mathrm{~mm}$ in diameter) within $48 \mathrm{~h}$ on R2A agar incubated at $30{ }^{\circ} \mathrm{C}$. Growth occurred at temperatures ranging from 5 to $37{ }^{\circ} \mathrm{C}$, but no growth was observed at $42{ }^{\circ} \mathrm{C}$ within 14 days. Growth occurred at $\mathrm{pH} 6-10$. Strains $4 \mathrm{C} 1-\mathrm{a}^{\mathrm{T}}$ and 4C1-b were able to grow with up to 100 p.p.m. 4-CP, removing it completely from the medium, and were resistant at up to 200 p.p.m. 4-CP for 4 weeks. Cells of the two strains were aerobic, Gram-positive, non-motile, non-spore-forming and displayed a rod-coccus life cycle. Colonies were creamy white, translucent and circular with entire edges. 
Analysis of the almost-complete 16S rRNA gene sequences (approximately $1450 \mathrm{nt}$ ) of strains $4 \mathrm{C} 1-\mathrm{a}^{\mathrm{T}}$ and $4 \mathrm{C} 1-\mathrm{b}$ indicated that they belonged to the genus Arthrobacter. Levels of $16 \mathrm{~S}$ rRNA gene sequence similarity among the type strains of recognized species of the genus Arthrobacter ranged from 91.8 to $99.8 \%$. Strains $4 \mathrm{C} 1-\mathrm{a}^{\mathrm{T}}$ and $4 \mathrm{C} 1-\mathrm{b}$, which shared $99.9 \%$ sequence similarity, showed highest levels of sequence similarity to A. chlorophenolicus DSM $12829^{\mathrm{T}}$, A. oxydans DSM $20119^{\mathrm{T}}$ and A. scleromae JCM $12642^{\mathrm{T}}(98.4,97.8$ and $97.8 \%$, respectively). Levels of sequence similarity with respect to the type strains of other recognized Arthrobacter species (except A. viscosus) were in the range $93.1-97.7 \%$. In the neighbour-joining phylogenetic tree, strains $4 \mathrm{C} 1-\mathrm{a}^{\mathrm{T}}$ and $4 \mathrm{C} 1-\mathrm{b}$ occupied a distinct position, clustering only with A. chlorophenolicus (Fig. 1), but they were also closely related to $A$. oxydans, $A$. polychromogenes, A. scleromae and A. sulfonivorans. An extended version of the $16 \mathrm{~S}$ rRNA gene phylogenetic tree, including all recognized Arthrobacter species except $A$. viscosus, is available as Supplementary Fig. S1 in IJSEM Online.

The chemotaxonomic properties of strains $4 \mathrm{C} 1-\mathrm{a}^{\mathrm{T}}$ and 4C1-b were consistent with their classification within the genus Arthrobacter (Huang et al., 2005; Keddie et al., 1986; Reddy et al., 2002). The major menaquinone was MK-9 $\left(\mathrm{H}_{2}\right)$; small amounts of MK- $8\left(\mathrm{H}_{2}\right)$ and MK- $7\left(\mathrm{H}_{2}\right)$ were also present. The predominant fatty acids were anteiso- $\mathrm{C}_{15: 0}(56.4 \pm 0.4 \%$; mean $\pm \mathrm{SD}$ of 2 determina-

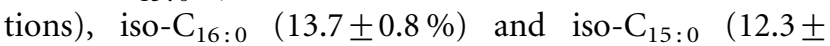
$2.1 \%)$. The cell-wall peptidoglycan was of $\mathrm{A} 3 \alpha$ type with an L-Lys-L-Ser-L-Thr-L-Ala interpeptide bridge, which is also found in closely related Arthrobacter species, i.e. A. chlorophenolicus, A. oxydans, A. polychromogenes, A. scleromae and A. sulfonivorans. The cell-wall sugars were galactose, glucose and rhamnose. Detailed chemotaxonomic characteristics of strains $4 \mathrm{C} 1-\mathrm{a}^{\mathrm{T}}$ and $4 \mathrm{C} 1-\mathrm{b}$ are summarized in Table 1.

However, strains $4 \mathrm{C} 1-\mathrm{a}^{\mathrm{T}}$ and $4 \mathrm{C} 1-\mathrm{b}$ showed significant differences from their closest related Arthrobacter species in terms of acid production, carbon source utilization and substrate hydrolysis, and also with regard to colony colour. The physiological and biochemical characteristics of strains $4 \mathrm{C} 1-\mathrm{a}^{\mathrm{T}}$ and $4 \mathrm{C} 1-\mathrm{b}$ are summarized in Table 2 and in the species description below.

Levels of DNA-DNA hybridization between strain $4 \mathrm{C} 1-\mathrm{a}^{\mathrm{T}}$ and the type strains of $A$. chlorophenolicus, A. oxydans, A. scleromae, A. polychromogenes and A. sulfonivorans were $38,22,15,25$, $18 \%$, respectively, whereas the level between strains $4 \mathrm{C} 1-\mathrm{a}^{\mathrm{T}}$ and 4C1-b was $93 \%$. Consequently, the DNA-DNA hybridization results confirmed that strains $4 \mathrm{C} 1-\mathrm{a}^{\mathrm{T}}$ and $4 \mathrm{C} 1-\mathrm{b}$ represent a distinct genomic species (Wayne et al., 1987).

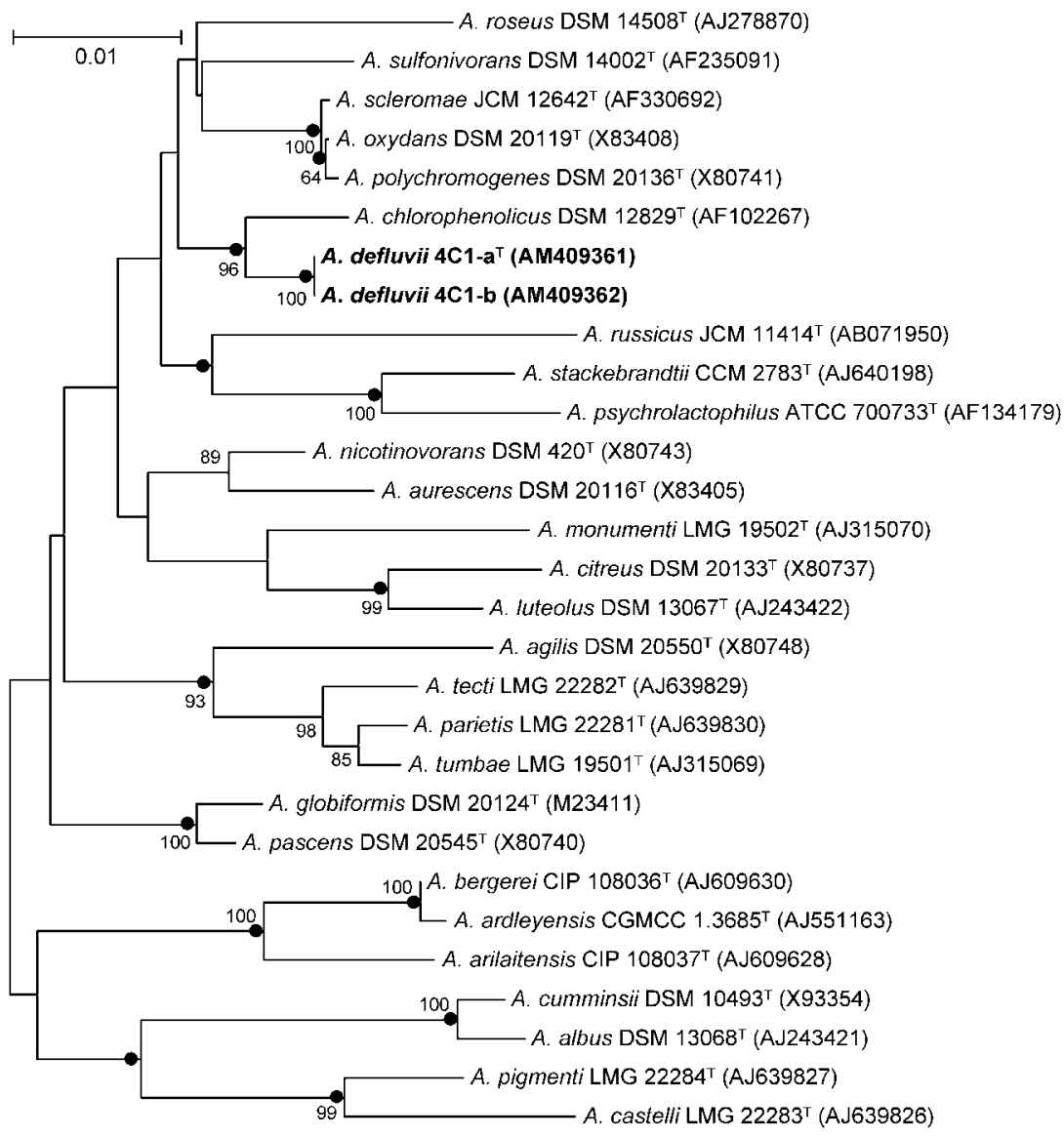

Fig. 1. Phylogenetic tree based on $16 \mathrm{~S}$ rRNA gene sequences, constructed according to the neighbour-joining method (Saitou \& Nei, 1987), showing the positions of strains $4 \mathrm{C} 1$ $\mathrm{a}^{\top}$ and $4 \mathrm{C} 1-\mathrm{b}$ among species of the genus Arthrobacter. Solid circles indicate generic branches of the tree that were also found with the maximum-parsimony treeing algorithm (Fitch, 1971). Numbers at branch points refer to bootstrap percentages (from 1000 resamplings; only values above $50 \%$ are shown). Bar, 1 substitution per 100 nucleotide positions. An extended version of this tree is available as Supplementary Fig. S1 in IJSEM Online. 
Table 1. Chemotaxonomic characteristics of strains $4 \mathrm{C} 1-\mathrm{a}^{\top}$ and $4 \mathrm{C} 1-\mathrm{b}$ (Arthrobacter defluvii sp. nov.) and the type strains of closely related Arthrobacter species

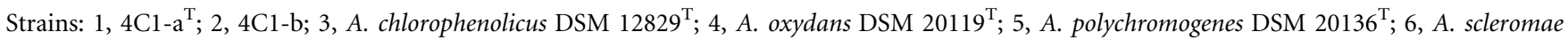
JCM $12642^{\mathrm{T}} ; 7$, A. sulfonivorans DSM 14002 $2^{\mathrm{T}}$. Data are from Borodina et al. (2002), Huang et al. (2005), Kodama et al. (1992), Reddy et al. (2002), Westerberg et al. (2000) and the present study. Fatty acids are listed using standard abbreviations (number of carbon atoms: number of double bonds). ND, Not detected.

\begin{tabular}{|c|c|c|c|c|c|c|c|}
\hline Characteristic & 1 & 2 & 3 & 4 & 5 & 6 & 7 \\
\hline Cell-wall sugars* & Gal, Glc, Rha & Gal, Glc, Rha & Gal, Glc, Rha & Gal, Glc & Gal & Gal, Glc & Gal, Glc \\
\hline \multicolumn{8}{|l|}{ Fatty acid composition (\%) } \\
\hline iso- $\mathrm{C}_{14: 0}$ & 3.3 & 3.4 & 2.0 & 1.8 & 2.3 & 2.3 & 3.1 \\
\hline $\mathrm{C}_{14: 0}$ & 1.7 & 1.8 & 1.8 & 2.0 & 2.9 & 1.1 & 2.4 \\
\hline $\mathrm{C}_{15: 0}$ & ND & ND & 0.6 & ND & 0.8 & ND & $\mathrm{ND}$ \\
\hline iso- $\mathrm{C}_{16: 1}$ & 0.6 & $\mathrm{ND}$ & ND & $\mathrm{ND}$ & 1.1 & 3.4 & 0.9 \\
\hline iso- $\mathrm{C}_{16: 0}$ & 12.8 & 14.5 & 10.2 & 8.6 & 6.7 & 6.2 & 12.6 \\
\hline $\mathrm{C}_{16: 1} \omega 7 c$ & $\mathrm{ND}$ & $\mathrm{ND}$ & $\mathrm{ND}$ & 2.2 & 4.3 & 4.0 & 3.2 \\
\hline $\mathrm{C}_{16: 0}$ & 3.6 & 4.5 & 6.5 & 5.1 & 5.6 & 2.8 & 5.9 \\
\hline
\end{tabular}

${ }^{\star}$ Gal, Galactose; Glc, glucose; Rha, rhamnose.

On the basis of the genotypic and phenotypic data, strains $4 \mathrm{C} 1-\mathrm{a}^{\mathrm{T}}$ and $4 \mathrm{C} 1-\mathrm{b}$ are considered to represent a novel species of the genus Arthrobacter, for which the name Arthrobacter defluvii sp. nov. is proposed.

\section{Description of Arthrobacter defluvii sp. nov.}

Arthrobacter defluvii (de.flu'vi.i. L. gen. n. defluvii of sewage).

Cells are aerobic, Gram-positive, non-motile, non-sporeforming and display a rod-coccus life cycle. The cocci are approximately $0.6 \mu \mathrm{m}$ in diameter. The rods are approximately $0.4-0.6 \times 1.0-2.0 \mu \mathrm{m}$ in size. Catalase-positive but oxidase-negative. Growth occurs at $5-37{ }^{\circ} \mathrm{C}$ (optimum 25 $30{ }^{\circ} \mathrm{C}$ ) and at $\mathrm{pH}$ 6-10 (optimum $\mathrm{pH} 7-8$ ). Growth occurs in the presence of up to $5 \% \mathrm{NaCl}$ but not with $10 \% \mathrm{NaCl}$. Colonies are creamy white, translucent and circular with entire edges. Indole and $\mathrm{H}_{2} \mathrm{~S}$ are not produced. VogesProskauer reaction is positive. Nitrate is reduced but nitrite is not. Aesculin, casein and starch (weakly) are hydrolysed, but gelatin and urea are not. Acid is produced from ribose, D-xylose, inositol, mannitol and aesculin, but not from glycerol, erythritol, D-arabinose, L-arabinose, L-xylose, adonitol, methyl $\beta$-D-xylose, galactose, glucose, fructose, mannose, sorbose, rhamnose, dulcitol, sorbitol, methyl $\alpha$ D-mannoside, methyl $\alpha$-D-glucoside, $N$-acetylglucosamine, amygdalin, arbutin, salicin, cellobiose, maltose, lactose, melibiose, sucrose, trehalose, inulin, melezitose, raffinose, starch, glycogen, xylitol, gentiobiose, turanose, D-lyxose, Dtagatose, D-fucose, L-fucose, D-arabitol, L-arabitol, gluconate, 2-ketogluconate or 5-ketogluconate. The following compounds are utilized as sole carbon sources: mannitol, rhamnose, D-glucose, salicin, D-ribose, melibiose, L-fucose, sucrose, maltose, mannose, L-arabinose, propionate, malonate, valerate, acetate, citrate, gluconate, DL-lactate, malate, phenylacetate, histidine, L-alanine, 2-ketogluconate, 5-ketogluconate, 3-hydroxybutyrate, glycogen, 3hydroxybenzoate, 4-hydroxybenzoate, L-proline and Lserine. The following carbon sources are not utilized: $\mathrm{N}$ acetylglucosamine, inositol, D-sorbitol, adipate, itaconate, suberate and caprate. According to the results from the API ZYM tests, 2-naphthyl butyrate, L-leucyl 2-naphthylamide, 2-naphthyl phosphate (pH 5.4), 6-bromo-2-naphthyl $\alpha$-Dgalactopyranoside and 2-naphthyl $\alpha$-D-glucopyranoside are hydrolysed, but 2-naphthyl phosphate ( $\mathrm{pH} 8.5)$, 2naphthyl caprylate, 2-naphthyl myristate, L-valyl 2naphthylamide, L-cystyl 2-naphthylamide, $N$-benzoyl-DLarginine 2-naphthylamide, $N$-glutaryl-phenylalanine 2naphthylamide, naphthol-AS-BI-phosphate, 2-naphthyl $\beta$-D-galactopyranoside, naphthol-AS-BI- $\beta$-D-glucuronide, 6-bromo-2-naphthyl $\beta$-D-glucopyranoside, 1-naphthyl $N$ acetyl- $\beta$-D-glucosaminide, 6-bromo-2-naphthyl $\beta$-D-mannopyranoside and 2-naphthyl $\alpha$-L-fucopyranoside are not hydrolysed. The major menaquinone is MK- $9\left(\mathrm{H}_{2}\right)$; small amounts of MK-8 $\left(\mathrm{H}_{2}\right)$ and MK-7 $\left(\mathrm{H}_{2}\right)$ are also present. Predominant fatty acids are anteiso- $\mathrm{C}_{15: 0}(56.4 \pm 0.4 \%)$, 
Table 2. Differential physiological and biochemical characteristics between strain $4 \mathrm{C} 1-\mathrm{a}^{\top}$ (Arthrobacter defluvii sp. nov.) and the type strains of closely related Arthrobacter species

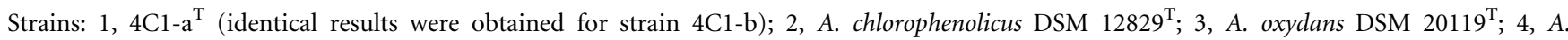
polychromogenes DSM 20136 $;$; , A. scleromae JCM $12642^{\mathrm{T}}$; 6, A. sulfonivorans DSM $14002^{\mathrm{T}}$. Data are from Borodina et al. (2002), Huang et al. (2005), Kodama et al. (1992), Reddy et al. (2002), Westerberg et al. (2000) and the present study. +, Positive; (+), weakly positive; -, negative; NA, not applicable.

\begin{tabular}{|c|c|c|c|c|c|c|}
\hline Characteristic & 1 & 2 & 3 & 4 & 5 & 6 \\
\hline $\begin{array}{l}\text { Colony colour on peptone-carbohydrate } \\
\text { medium }\end{array}$ & Creamy white & Pearl grey & Pearl grey to yellow & Blue & White & Creamy yellow \\
\hline Motility & - & + & - & - & - & + \\
\hline Nitrate reduction & + & - & + & + & $(+)$ & - \\
\hline \multicolumn{7}{|l|}{ Growth at/on/in: } \\
\hline $5{ }^{\circ} \mathrm{C}$ & + & + & - & - & - & + \\
\hline $37^{\circ} \mathrm{C}$ & + & + & + & + & + & - \\
\hline $42{ }^{\circ} \mathrm{C}$ & - & - & - & + & - & - \\
\hline $5 \% \mathrm{NaCl}$ & + & + & + & + & + & - \\
\hline $10 \% \mathrm{NaCl}$ & - & - & + & - & - & - \\
\hline Nicotine & - & + & + & - & - & - \\
\hline Mineral salts medium without biotin & + & + & - & - & + & + \\
\hline $\begin{array}{l}\text { Colony colour on nicotine-yeast extract } \\
\text { medium }\end{array}$ & $\mathrm{NA}$ & Pearl grey & Blue & NA & $\mathrm{NA}$ & NA \\
\hline \multicolumn{7}{|l|}{ Acid production from: } \\
\hline L-Arabinose & - & + & + & - & - & - \\
\hline Galactose & - & + & + & + & - & + \\
\hline Glucose & - & + & + & + & - & + \\
\hline Rhamnose & - & + & + & - & - & - \\
\hline Inositol & + & - & + & - & - & + \\
\hline Mannitol & + & - & + & - & + & + \\
\hline Maltose & - & + & + & - & - & - \\
\hline Lactose & - & + & + & + & - & + \\
\hline Trehalose & - & + & + & + & - & - \\
\hline \multicolumn{7}{|l|}{ Utilization of: } \\
\hline Salicin & + & - & - & + & + & + \\
\hline Inositol & - & + & - & - & $(+)$ & + \\
\hline L-Fucose & + & - & - & - & - & - \\
\hline D-Sorbitol & - & + & + & + & + & + \\
\hline \multicolumn{7}{|l|}{ Hydrolysis of: } \\
\hline Gelatin & - & - & $(+)$ & + & - & + \\
\hline Starch & $(+)$ & - & + & $(+)$ & + & - \\
\hline 2-Naphthyl butyrate & + & - & - & + & - & - \\
\hline 2-Naphthyl phosphate $(\mathrm{pH} 5.4)^{\star}$ & + & - & - & - & - & - \\
\hline 2-Naphthyl $\beta$-D-galactopyranoside ${ }^{*}$ & - & + & + & + & - & + \\
\hline $\begin{array}{l}\text { 6-Bromo-2-naphthyl } \\
\beta \text {-D-glucopyranoside }\end{array}$ & - & + & - & + & - & - \\
\hline
\end{tabular}

${ }^{*}$ Data from API ZYM tests. The intensity of the colour was measured on a scale from 0 to 5 and was interpreted as negative at values of 0 or 1 and positive at values of 2-5 (Mudarris et al., 1994).

iso- $\mathrm{C}_{16: 0}(13.7 \pm 0.8 \%)$ and iso- $\mathrm{C}_{15: 0}(12.3 \pm 2.1 \%)$. Cellwall peptidoglycan is of A3 $\alpha$ type with an L-Lys-L-Ser-LThr-L-Ala interpeptide bridge. Cell-wall sugars are galactose, glucose and rhamnose. The $\mathrm{G}+\mathrm{C}$ content of the DNA is $63.5-64.4 \mathrm{~mol} \%(64.4 \mathrm{~mol} \%$ for the type strain).

The type strain, 4 C1- $\mathrm{a}^{\mathrm{T}}\left(=\mathrm{KCTC} 19209^{\mathrm{T}}=\mathrm{DSM} 18782^{\mathrm{T}}\right)$, was isolated from sewage flowing into Geumho River in
Daegue, Korea. 4C1-b, isolated from the same source, is a second strain of the species.

\section{Acknowledgements}

This work was supported by a grant (NMM0100721) from the Ministry of Science and Technology (MOST) of the Republic of Korea. 


\section{References}

Bates, R. G. \& Bower, V. E. (1956). Alkaline solutions for pH control. Anal Chem 28, 1322-1324.

Borodina, E., Kelly, D. P., Schumann, P., Rainey, F. A., Ward-Rainey, N. L. \& Wood, A. P. (2002). Enzymes of dimethylsulfone metabolism and the phylogenetic characterization of the facultative methylotrophs Arthrobacter sulfonivorans sp. nov., Arthrobacter methylotrophus sp. nov., and Hyphomicrobium sulfonivorans sp. nov. Arch Microbiol 177, 173-183.

Conn, H. J. \& Dimmick, I. (1947). Soil bacteria similar in morphology to Mycobacterium and Corynebacterium. J Bacteriol 54, 291-303.

Ezaki, T., Hashimoto, Y. \& Yabuuchi, E. (1989). Fluorometric deoxyribonucleic acid-deoxyribonucleic acid hybridization in microdilution wells as an alternative to membrane filter hybridization in which radioisotopes are used to determine genetic relatedness among bacterial strains. Int J Syst Bacteriol 39, 224-229.

Felsenstein, J. (1985). Confidence limits on phylogenies: an approach using the bootstrap. Evolution 39, 783-791.

Fitch, W. M. (1971). Toward defining the course of evolution: minimum change for a specific tree topology. Syst Zool 20, 406-416.

Gerhardt, P., Murray, R. G. E., Wood, W. A. \& Krieg, N. R. (editors) (1994). Methods for General and Molecular Bacteriology. Washington, DC: American Society for Microbiology.

Gomori, G. (1955). Preparation of buffers for use in enzyme studies. Methods Enzymol 1, 138-146.

Hall, T. A. (1999). BioEdit: a user-friendly biological sequence alignment editor and analysis program for Windows 95/98/NT. Nucleic Acids Symp Ser 41, 95-98.

Huang, Y., Zhao, N., He, L., Wang, L., Liu, Z., You, M. \& Guan, F. (2005). Arthrobacter scleromae sp. nov. isolated from human clinical specimens. J Clin Microbiol 43, 1451-1455.

Ishikawa, T. \& Yokota, A. (2006). Reclassification of Arthrobacter duodecadis Lochhead 1958 as Tetrasphaera duodecadis comb. nov. and emended description of the genus Tetrasphaera. Int J Syst Evol Microbiol 56, 1369-1373.

Jones, D. \& Keddie, R. M. (1992). The genus Arthrobacter. In The Prokaryotes: a Handbook on the Biology of Bacteria: Ecophysiology, Isolation, Identification, Applications, 2nd edn, vol. 2, pp. 1283-1299. Edited by A. Balows, H. G. Trüper, M. Dworkin, W. Harder \& K. H. Schleifer. New York: Springer.

Jukes, T. H. \& Cantor, C. R. (1969). Evolution of protein molecules. In Mammalian Protein Metabolism, vol. 3, pp. 21-132. Edited by H. N. Munro. New York: Academic Press.

Kageyama, A., Takahashi, Y., Morisaki, K. \& Omura, S. (2008). Arthrobacter oryzae sp. nov. and Arthrobacter humicola sp. nov. Int $J$ Syst Evol Microbiol 58, 53-56.

Kämpfer, P. \& Kroppenstedt, R. M. (1996). Numerical analysis of fatty acid patterns of coryneform bacteria and related taxa. Can J Microbiol 42, 989-1005.

Keddie, R. M., Collins, M. D. \& Jones, D. (1986). Genus Arthrobacter Conn and Dimmick 1947, 300 ${ }^{\mathrm{AL}}$. In Bergey's Manual of Systematic Bacteriology, vol. 2, pp. 1288-1301. Edited by P. H. A. Sneath, N. S. Mair, M. E. Sharpe \& J. G. Holt. Baltimore: Williams \& Wilkins.

Klatte, S., Rainey, F. A. \& Kroppenstedt, R. M. (1994). Transfer of Rhodococcus aichiensis Tsukamura 1982 and Nocardia amarae Lechevalier \& Lechevalier 1974 to the genus Gordona as Gordona aichiensis comb. nov. and Gordona amarae comb. nov. Int J Syst Bacteriol 44, 769-773.

Koch, C., Schumann, P. \& Stackebrandt, E. (1995). Reclassification of Micrococcus agilis (Ali-Cohen 1889) to the genus Arthrobacter as
Arthrobacter agilis comb. nov. and emendation of the genus Arthrobacter. Int J Syst Bacteriol 45, 837-839.

Kodama, Y., Yamamoto, H., Amano, N. \& Amachi, T. (1992). Reclassification of two strains of Arthrobacter oxydans and proposal of Arthrobacter nicotinovorans sp. nov. Int J Syst Bacteriol 42, 234-239.

Kumar, S., Tamura, K., Jakobsen, I. B. \& Nei, M. (2001). MEGA2: molecular evolutionary genetics analysis software. Bioinformatics 17, 1244-1245.

Miller, J. H. (1972). Experiments in Molecular Genetics. Cold Spring Harbor, NY: Cold Spring Harbor Laboratory Press.

Mudarris, M., Austin, B., Segers, P., Vancanneyt, M., Hoste, B. \& Bernardet, J. F. (1994). Flavobacterium scophthalmum sp. nov., a pathogen of turbot (Scophthalmus maximus L.). Int J Syst Bacteriol 44, 447-453.

Rainey, F. A., Ward-Rainey, N., Kroppenstedt, R. M. \& Stackebrandt, E. (1996). The genus Nocardiopsis represents a phylogenetically coherent taxon and a district actinomycete lineage: proposal of Nocardiopsaceae fam. nov. Int J Syst Bacteriol 46, 1088-1092.

Reddy, G. S. N., Prakash, J. S. S., Matsumoto, G. I., Stackebrandt, E. \& Shivaji, S. (2002). Arthrobacter roseus sp. nov., a psychrophilic bacterium isolated from an Antarctic cyanobacterial mat sample. Int $J$ Syst Evol Microbiol 52, 1017-1021.

Saitou, N. \& Nei, M. (1987). The neighbor-joining method: a new method for reconstructing phylogenetic trees. Mol Biol Evol 4, 406-425.

Sasser, M. (1990). Identification of bacteria by gas chromatography of cellular fatty acids, MIDI Technical Note 101. Newark, DE: MIDI Inc.

Schleifer, K. H. \& Kandler, O. (1972). Peptidoglycan types of bacterial cell walls and their taxonomic implications. Bacteriol Rev 36, 407-477.

Shin, Y. K., Lee, J.-S., Chun, C. O., Kim, H.-J. \& Park, Y.-H. (1996). Isoprenoid quinone profiles of the Leclercia adecarboxylata KCTC $1036^{\mathrm{T}}$. J Microbiol Biotechnol 6, 68-69.

Skerman, V. B. D. (1967). A Guide to the Identification of the Genera of Bacteria, 2nd edn. Baltimore: Williams \& Wilkins.

Stackebrandt, E., Fowler, V. J., Fiedler, F. \& Seiler, H. (1983). Taxonomic studies on Arthrobacter nicotianae and related taxa: description of Arthrobacter uratoxydans sp. nov. and Arthrobacter sulfureus sp. nov. and reclassification of Brevibacterium protophormiae as Arthrobacter protophormiae comb. nov. Syst Appl Microbiol 4, 470-486.

Staneck, J. L. \& Roberts, G. D. (1974). Simplified approach to identification of aerobic actinomycetes by thin-layer chromatography. Appl Microbiol 28, 226-231.

Tamaoka, J. \& Komagata, K. (1984). Determination of DNA base composition by reversed-phased high-performance liquid chromatography. FEMS Microbiol Lett 25, 125-128.

Tarrand, J. J. \& Groschel, D. H. M. (1982). Rapid, modified oxidase test for oxidase-variable bacterial isolates. J Clin Microbiol 16, 772-774.

Thompson, J. D., Gibson, T. J., Plewniak, F., Jeanmougin, F. \& Higgins, D. G. (1997). The CLUSTAL_X windows interface: flexible strategies for multiple sequence alignment aided by quality analysis tools. Nucleic Acids Res 25, 4876-4882.

Wayne, L. G., Brenner, D. J., Colwell, R. R., Grimont, P. A. D., Kandler, O., Krichevsky, M. I., Moore, L. H., Moore, W. E. C., Murray, R. G. E. \& other authors (1987). International Committee on Systematic Bacteriology. Report of the ad hoc committee on reconciliation of approaches to bacterial systematics. Int J Syst Bacteriol 37, 463-464.

Westerberg, K., Elväng, A. M., Stackebrandt, E. \& Jansson, J. K. (2000). Arthrobacter chlorophenolicus sp. nov., a new species capable of degrading high concentrations of 4-chlorophenol. Int J Syst Evol Microbiol 50, 2083-2092. 